DOI: 10.18413/2313-8955-2015-1-4-69-74

\author{
Martynova O.V. ${ }^{1}$ \\ Gureev V.V. ${ }^{2}$ \\ Pokrovskiy M.V. ${ }^{3}$ \\ Martynov M.A. ${ }^{4}$ \\ Solgalova A.S. ${ }^{5}$ \\ Antsiferov 0.V. ${ }^{6}$
}

\title{
SIMULATION OF TOTAL BRAIN ISCHEMIA IN RATS
}

1) graduate student of the Department of pharmacology of Medical University of NRU BelSU, 85 Pobedy St., Belgorod, 308015, Russia. E-mail: m.olga91@ mail.ru

2) associate professor of pharmacology, candidate of medical sciences of the Department of pharmacology of Medical University of NRU BelSU, 85 Pobedy St., Belgorod, 308015, Russia

3) professor of the Department of pharmacology, doctor of medical sciences, of Medical University of NRU BelSU, 85 Pobedy St., Belgorod, 308015, Russia

4) ordinator of department of hospital surgery of the Department of pharmacology of Medical University of NRU BelSU, 85 Pobedy St., Belgorod, 308015, Russia

5) graduate student of the Department of pharmacology of Medical University of NRU BelSU, 85 Pobedy St., Belgorod, 308015, Russia

6) graduate student of the Department of pharmacology

of Medical University of NRU BelSU, 85 Pobedy St., Belgorod, 308015, Russia

SUMMARY. This paper deals with the study of the dependence of psycho neurological deficit in rats on the severity of brain damage, conducted on the four-vascular models of total cerebral ischemia. The obtained results demonstrate a tendency to deterioration of neuropsychiatric status of the animals with increasing severity of ischemic brain damage that allows suggesting the severity of ischemic brain damage and its correction by the degree of behavioral disorders.

Keywords: total brain ischemia, neurologic deficiency, rats.

\section{Мартынова O.B. ${ }^{1}$ \\ Гуреев В.В. ${ }^{2}$ \\ Покровский М.В. ${ }^{3}$ \\ Мартынов М.A. ${ }^{4}$ \\ Солгалова А.С. ${ }^{5}$ \\ Анциферов O.B. ${ }^{6}$}

\author{
МОДЕЛИРОВАНИЕ ТОТАЛЬНОЙ ИШЕМИИ ГОЛОВНОГО МОЗГА \\ У КРЫС
}

1) аспирант кафедры фармакологии Медицинского института НИУ «БелГУ»,

308015, Белгород, ул. Победы, 85, Россия; E-mail: m.olga91@ mail.ru

2) к.м.н., доцент кафедры фармакологии, Медицинского института НИУ «БелГУ», 308015, Белгород, ул. Победы, 85, Россия

$3)$ д.м.н., профессор кафедры фармакологии, Медицинского института НИУ «БелГУ», 308015, Белгород, ул. Победы, 85, Россия

4) ординатор кафедры госпитальной хирургии Медицинского института НИУ «БелГУ», 308015, Белгород, ул. Победы, 85, Россия

5) аспирант кафедры фармакологии Медицинского института НИУ «БелГУ», 308015, Белгород, ул. Победы, 85, Россия

6) аспирант кафедры фармакологии Медицинского института НИУ «БелГУ», 308015, Белгород, ул. Победы, 85, Россия

\begin{abstract}
Аннотация. Проведено исследование зависимости психоневрологического дефицита у крыс от степени тяжести повреждения головного мозга, на четырехсосудистой модели тотальной ишемии головного мозга. Результаты исследования доказывают тенденцию ухудшения психоневрологического статуса животных при увеличении тяжести ишемического повреждения головного мозга, что позволяет по степени нарушения поведенческих реакций судить о тяжести ишемического поражения головного мозга и его коррекции.
\end{abstract}

Ключевые слова: тотальная ишемия головного мозга, неврологический дефицит, крысы. 


\section{Introduction}

The structure of the brain vascular diseases has changed in the last ten years due to the rise of ischemic forms. Total cerebral ischemia by prevalence takes one of the leading positions among cerebrovascular diseases. As a result of this type of ischemia a cognitive impairment occurs that leads to social maladjustment of patients.

Total ischemia is a complete loss of the three functions of the local blood supply such as the delivery of oxygen to the tissue, the delivery of plastic materials, and removal of metabolic products. Total ischemia can be due to either the complete stagnation of or partial reduction in blood flow. In this case, the oxygeninvolving processes stop, and the cells suffer a shortage of high-energy phosphates that leads to disruption of ion transport. Energy production decreases, ATP production is no longer sufficient to ensure the energy needs of the neuron, which is followed by the impairment of cellular homeostasis $[1,2]$.

Natural endogenous mechanisms of cytoprotection in ischemic damage is a series of biological processes, combined in the term «phenomenon of ischemic preconditioning». Ischemic preconditioning is an increase in the tissue resistance to the ischemic and reperfusion injury, which occurs after a short transient ischemic episode $[3,4]$.

In recent years, during the process of development of new drugs much attention has been paid to biological processes occurring in ischemic preconditioning. On the one hand, there are already drugs that cause activation of the biological processes of ischemic preconditioning, while on the other their triggers are a series of humoral factors occurring in response to ischemia and, therefore, there is a prospect to develop their pharmacological equivalents [4]. Therefore, searching for drugs to correct ischemic brain damage, which mechanisms of action are based on biological processes occurring in ischemic preconditioning, remains relevant.

Neurological deficit is a consequence of cerebral ischemia. Neurological deficits means changes in the standard neurological status (paresis, plegia, sensitivity disturbance, dizziness, etc.). Increase in neurological symptoms leads to the appearance of specific or dominant syndrome [1].

A series of tests are used to assess the neurological deficit in rats. The most informative are a «Elevated plus maze», «Morris water maze», «Open field», «Swauk-test», a swimming despair test, and the behavioral study on the «Infrared activity monitor». We used in our study the tests such as «Elevated plus maze» and «Infrared activity monitor».
«Elevated plus maze» is a behavioral test for the study of activity, emotional state, and the level of anxiety in laboratory animals.

«Infrared activity monitor» includes a twodimensional square frame and a system of infrared rays detecting the animal movements. IR Actimeter ensures testing of any motor activity, the number and duration of episodes of hindlimb rising, stereotypical movements, as well as exploratory behavior in a model of «perforated field» under day and night lighting.

Objective of the research: to study the behavioral reactions of rats under simulation of total brain ischemia.

Problem of the research: to choose the appropriate behavioral tests and methods during the evaluation of neurological abnormalities on the model of total cerebral ischemia in rats.

\section{Materials and methods}

The experiment was conducted on 40 adult male Wistar rats, weighing 230-250 g. The animals were kept under standard vivarium conditions of NRU «BSU» with free access to food and water. Animal welfare and the experimental set up were in compliance with the requirements of the order No. 1179 MH USSR of 10.11.1983 and No. 267 of the Russian Federation of 19.06.2003, as well as international rules of the «Guide for the Care and USE of Laboratory Animals».

All rats were randomized by the degree of resistance to hypoxia.

Rats were divided into 4 groups $(n=10)$. The first group of animals underwent sham operation. In the second group of rats, we simulated four-vascular total cerebral ischemia for 3 minutes, the third group - for 4 minutes, and the fourth group -4.5 minutes. We used a modified approach by Mitsuo Yamaguchi et al. [6]. The main advantage of this model - low injury rate. The rats were anesthetized («Zoletil 100» $60 \mathrm{mg} / \mathrm{ml}$, and chloral hydrate $150 \mathrm{mg} / \mathrm{ml}$ ) and the carotid arteries were isolated. Tracheal tube and thyroid were moved aside to allow access to the spine. Occlusion of the vertebral arteries was performed at the level of $\mathrm{C} 2-\mathrm{C} 3$, and then the adequacy of methodology implementation completeness was assessed [2]. When clamping the two carotid arteries there was a sharp reduction in the EEG amplitude. Clamping time was 3, 4, and 4.5 minutes, after which the clips were removed and reperfusion was observed.

The assessment of neurological status of the animal was carried out in 3 stages: assessment of the dynamics of neurological disorders on a McGrow scale on day $1,3,7$ and $14[1,5]$; on the first day - 
«Elevated plus maze»; on the second day - «Infrared activity monitor» [3].

At the initial stage of the experiment, all animals underwent behavioral tests «Elevated plus maze» and «Infrared activity monitor».

The assessment of the disease impact on motor and orienting-exploratory activity of animals with the tests «Infrared activity monitor» and «Elevated plus maze» was conducted in relation to the time, and for the first time an assessment of neurological deficits in animals was made.

Infrared activity monitor. A rat was placed in the center of the field of infrared activity monitor with infrared rays for 5 minutes. Further, the tracks (the scheme of movement and activity of the rats) and statistics of animal behavior were obtained.

Elevated plus maze.A rat was placed on the launch site of the maze, and then localized in either the «dark» or the «light» compartment. The recorded parameters: total time spent in the dark and light compartments of the maze, the number of upright postures, overhangs, defecation, and urination.

Neurological deficit in animals with pathology was determined on a Stroke-index McGraw scale [5] presented in Table 1 . The severity of the condition was estimated by the sum of the corresponding points. The number of rats was recorded:

- with mild symptoms (up to 2.5 points on a Stroke-index scale) - sluggishness in movements, limb weakness, unilateral hemiptosis, tremor, circus movements;

- with severe signs of neurological disorders (from 3 to 10 points) - paresis and paralysis of limbs, as well as lateral position.

Stroke-index McGraw neurological deficit assessment scale [5]:

\begin{tabular}{|l|l|}
\hline \multicolumn{1}{|c|}{ Symptoms } & \multicolumn{1}{c|}{ Points } \\
\hline Sluggishness & 0.5 \\
\hline Tremor & 1 \\
\hline Unilateral hemiptosis & 1 \\
\hline Bilateral hemiptosis & 1.5 \\
\hline Limb weakness & 1.5 \\
\hline Unilateral ptosis & 1.5 \\
\hline Bilateral ptosis & 1.5 \\
\hline Circus movements & 2.0 \\
\hline $1-4$ limb paresis & $2-5$ \\
\hline $1-4$ limb paralysis & $3-6$ \\
\hline Coma & 7.0 \\
\hline Death & 10.0 \\
\hline
\end{tabular}

Parametric data were processed by methods of variation statistics: variation series were tested for normal distribution; in case of its compliance, the quantitative values were characterized by the arithmetic mean $(\mathrm{M})$ and the arithmetic mean error (m); the statistical significance of the quantitative values was evaluated by the Student's t-test; the statistical significance of differences in nonparametric data was evaluated after their ranking by using Mann-Whitney nonparametric data test. All calculations were performed with the use of MicrosoftExcel 7.0 statistical software package.
Table 1

\section{Results and discussion}

Data received from the sham-operated animals, which have no statistical differences with the intact animals, were taken for control (Figure 1, Table 2).

The 3-minute cerebral ischemia in rats was followed by minimum neurological symptoms observed, which have no statistical differences with the sham operated group ( $>>0.05)$. On day 3, 7 and 14 there were no neurological symptoms observed (Table 2). 
The severity dynamics of neurological impairments in the studied groups (by average score in each group)

\begin{tabular}{|c|c|c|c|c|c|}
\hline \multirow{2}{*}{ Period } & \multicolumn{5}{|c|}{ Groups } \\
\cline { 2 - 6 } & intact & sham-operated & $\begin{array}{c}\text { 3-minute brain } \\
\text { ischemia }\end{array}$ & $\begin{array}{c}\text { 4-minute brain } \\
\text { ischemia }\end{array}$ & $\begin{array}{c}4.5 \text {-minute brain } \\
\text { ischemia }\end{array}$ \\
\hline day 1 & 0 & 0 & 0.15 & $1.85^{*}$ & $6.05^{*}$ \\
\hline day 3 & 0 & 0 & 0 & $1^{*}$ & $1^{*}$ \\
\hline day 7 & 0 & 0 & 0 & 0 & $10^{*}$ \\
\hline day 14 & 0 & 0 & 0 & $10^{*}$ \\
\hline
\end{tabular}

Note: $*$ when $(\mathrm{p}<0.05)$ in relation to sham-operated animals.

Table 3

Evaluation of the behavioral activity of animals in the experiment

\begin{tabular}{|c|c|c|c|c|c|}
\hline \multirow{2}{*}{ Criteria } & \multicolumn{5}{|c|}{ Groups } \\
\cline { 2 - 6 } & intact & sham-operated & 3-minute brain ischemia & 4-minute brain ischemia & 4.5 -minute brain ischemia \\
\hline Total activity & $10067 \pm 51$ & $849 \pm 50$ & $619 \pm 40$ & $505 \pm 34$ & $304 \pm 24$ \\
\hline Stereotyped movements & $79.40 \pm 5.88$ & $60.40 \pm 2.74$ & $40.10 \pm 2.37$ & $29.0 \pm 2.05$ & $21.40 \pm 1.33$ \\
\hline Maximum speed & $25.50 \pm 2.03$ & $24.68 \pm 2.10$ & $24.59 \pm 1.47$ & $23.88 \pm 1.98$ & $18.43 \pm 1.39$ \\
\hline Overall distance & $1728 \pm 81$ & $1257 \pm 51$ & $952 \pm 66$ & $818 \pm 44$ & $432 \pm 38$ \\
\hline Upright postures & $10.50 \pm 0.86$ & $10.10 \pm 0.80$ & $6.70 \pm 0.54$ & $4.30 \pm 0.42$ & $0 \pm 0.68$ \\
\hline Hangings & $4.80 \pm 0.66$ & $4.40 \pm 0.70$ & $3.30 \pm 0.36$ & $1.60 \pm 0.26$ & 0 \\
\hline
\end{tabular}

Note: $*$ when $(\mathrm{p}<0.05)$ in relation to sham-operated animals.

Neurological deficit in rats with 4-minute ischemic period had more severe symptoms as compared to animals with 3-minute ischemic episode ( $\mathrm{p}<0.05): 20 \%$ of the rats had paralysis of the left hind limb and the right eye hemiptosis. The total percentage of rats with hemiptosis is $30 \%$. There was also sluggishness in movements, limb weakness, and tremor, which disappeared by the 3rd day after pathology simulation. On day 3, 7 and 14 both the paralysis of the left hind limb and the right eye hemiptosis remain.

On the first day of assessment, the most pronounced neurologic deficit was observed in rats with ischemic episodes lasting 4.5 minutes. It had more severe symptoms $(\mathrm{p}<0.05)$ such as tremor, circus movement, paralysis of limbs, hemiptosis, some animals had ptosis of both eyes, and coma. On day 3 , fatal cases were observed in $60 \%$ of rats. On day 7 , the mortality was $100 \%$, which is characterized as a very severe neurological deficit.

Under simulation of three-minute cerebral ischemia, the behavioral disorders are manifested themselves in the reduced number of upright postures, defecation, and urination. There is a tendency to the reduced number of hangings in the elevated plus maze test $(p<0.05)$ (Table 3$)$. The motor activity of animals with four-minute cerebral ischemia was even lower $(\mathrm{p}<0.05)$. The investigation of animals with 4.5-minute ischemia is impossible due to coma. During the assessment of locomotor activity of the animals by the Infrared activity meter test we found that the activity of sham-operated rats decreases as compared to intact animals, but not significantly $(\mathrm{p}>0.05)$.

With the increase in time of cerebral ischemia in the experiment, the rat's activity decreases: there is a decrease in the total activity, number of stereotyped movements, maximum speed, and total distance. The rest period increases along with the time of cerebral ischemia $(\mathrm{p}<0.05)$.

Thus, the experiments clearly demostrate a tendency to deterioration of neuropsychiatric status of the animals with increasing severity of ischemic brain damage, that allows suggesting the severity of ischemic brain damage and its correction by the degree of behavioral disorders. Therefore, the impairment of psychoneurological status may serve as a criterion in the selection of the severity of ischemic damage in the experiment.

Note: the group of authors would like to thank the Department of Internal and Personnel Policy for 
the financial support of the research under the agreement No. 36-GVN of November 25, 2014.

\section{References:}

1. Gannushkina I.V. Cerebral blood flow in different types of circulatory brain hypoxia // Bulletin of the Russian Academy of Medical Sciences. 2000. No. 9. Pp. 22-27.

2. Miasishcheva O.V., Pokrovskii M.V., Gureev V.V., Antsiferov O.V., Martynov M.A. The experimental model of ischemic brain damage // Scientific papers of Belgorod State University. Medicine. Pharmacy. 2012. No. 11 (182) Edition 26/1. Pp. 123-127.

3. Shmonin A.A., Panov I.Iu., Simanenkova A.V., Prosvirnina M.S., Chekanov S.S., Melnikova E.V., Vlasov T.D. Endogenous neuroprotection in brain ischemia: erythropoietin, pre- and postconditioning // Annals of Clinical and Experimental Neurology. 2010. No. 3 (Vol. 4). Pp. 29-35.
4. Galagudza M.M., Blokhin I.O., Shmonin A.A., Mischenko K.A. Reduction of myocardial ischemiareperfusion injury with pre- and postconditioning: molecular mechanisms and therapeutic targets// CardiovascHematolDisord Drug Targets. 2008. №8(1). P.47-65.

5. McGraw C.P., Pashayan A.G., Wendel O.T. Cerebral infarction in the Mongo- lian gerbil exacerbated by phenoxybenzamine treatment// Stroke. 1976; 7(5): 485- 488.

6. Mitsuo Y., Calvert J.W., Kusaka G., Zhang J. H. One-Stage Anterior Approach for Four-Vessel Occlusion in Rat // Stroke. 2005. № 36. P. 22122214. 